УдК 341.234(497.1)"1920/1939"

323.15(497.1)"1920/1939"

DOI https://doi.org/10.31212/tokovi.2020.3.mic.27-52

Оригинални научни рад

Примљен: 17.6.2020.

Прихваћен:1. 10. 2020.

\author{
Srđan MIĆIĆ \\ Institute for Recent History of Serbia, Belgrade \\ srdjan.micic@inis.bg.ac.rs
}

\title{
Minority Petitions Against Yugoslav Authorities Before the League of Nations
}

\begin{abstract}
AвSTRACT: This article deals with Yugoslavia's tactics against Bulgarian and Hungarian minority petitions, which were filed before the League of Nations and later promoted before the European Congress of Nationalities. The analysis is based on the documents preserved in the Records of the Permanent Delegation in Geneva, which is the most reliable source on the tactics since other significant Yugoslav institutions have hardly been preserved at all.

KeY WORDS: Yugoslavia, Minority Rights, League of Nations, Bulgarians, Hungarians
\end{abstract}

After the World War I ended, four empires were dissolved and new states created in Central, Eastern and Southeastern Europe. The international order - formed through a strict differentiation between the victorious and defeated nations - became more complex due to unequal treatment given to different countries and nations at the Paris Peace Conference. One of the important factors was the selective implementation of the right of peoples to self-determination, which was combined with the definition of state borders based on ethnic, strategic, and geographical principles. The decisions made by the Principle Powers created a growing gap between nations that were content and those that were humiliated, dissatisfied, or considered to be falsely played. These differences raised the question of the future preservation of the international order 
and peace in Europe. ${ }^{1}$ One segment of that issue was the status of national minorities, which had an expected impact on future relations between the European nations. ${ }^{2}$

As in many other cases, the conclusion of the Paris Peace Conference on minority rights was a matter of compromise between the Great Powers. The Anglo-Saxons and the French had different standpoints in terms of preserving the international order. The Anglo-Saxons came to the same conclusion - albeit starting from different positions - that the enlarged and newly formed countries in Central, Eastern, and Southeastern Europe were stable and developed enough to cope with the complex questions of administration, including proper handling of issues of the ethnic diversity of their populations. The logical presumption was that those countries would have irresponsible foreign policies and as such would present a threat to the preservation of peace. ${ }^{3}$ Adversely, the French viewed the renewal of Germany's power as the biggest threat to the newly established international order. Since Poland and Czechoslovakia had a prominent role in creating the anti-German network, French interests were that the internal stability of these two countries could not be contested from abroad - particularly by the German minorities - and France

$1 \quad$ For further reading: David A. Aldeman, A Shattered Peace. Versailles 1919 and the Price We Pay TodAJ, (Hoboken: Wiley, 2008); Margaret MacMillan, Paris 1919: Six Months that changed the World, (New York: Random House, 2002).

2 Piotr Eberhardt, Ethnic Groups and Population Changes in Twentieth-Century Central-Easter Europe: History, Data and Analysis, (London - New York: Routledge, 2015²); Jerg Fiš, Pravo naroda na samoopredeljenje. Obuzdavanje jedne iluzije, (Beograd: Albatros plus, 2013), 149-178; Peter Hilpold, „Minderheitenschutz im Völkerbundsystem", Zur Entstehung des modernen Minderheitenschutzes in Europa. Handbuch der europäischen Volksgruppen, Band 3, Hrsg. Christoph Pan, Beate Sibylle Pfeil, (Wien New York: Springer, 2006), 157-159, 178-180, 182-183; Boris Krivokapić, „Zaštita manjina između dva svetska rata - osvrt na neke posebne slučajeve“, Međunarodni problemi 1-2 (2005), 100, 101; Oliver Zimmer, Nationalism in Europe, 1890-1940, (Basingstoke - New York: Macmillan, 2003), 59-61; Филип Лонгворт, Стварање Источне Европе. Од преисторије до посткомунизма, (Београд: Clio, 2002), 136139; Henri Kisindžer, Diplomatija I, (Beograd: Verzal Press, 1999), 186, 201, 202; Mark Mazower, Dark Continent: Europe Twentieth-Century, (London: Penguine Books, 1999), 51-66; Иштван Бибо, Беда малих источноевропских држава, (Сремски Карловци - Нови Сад: ИК Зорана Стојановића, 1996), 50-52, 67-71, 74-75; Hermann Weber, „Der Minderheitenschutzes des Völkerbundes“, Friedenssichernde Aspekte der Minderheitenschutzes in der Ära des Völkerbundes und der Vereinten Nationen in Europa, Hrsg. Manfred Mohr, (Berlin-Heidelberg: Springer-Verlag, 1996), 6-9; Sebastian Bartsch, Minderheitenschutz in der internationalen Politik. Völkerbund und KSZE/OSZE in neuer Perspektive, (Opladen: Westdeutscher Verlag, 1995), 67-68, 70-71, 73-85.

3 MacMillan, Paris 1919, 59; Fiš, Pravo naroda na samoopredeljenje, 162, 163; Bartsch, Minderheitenschutz, 66, 71-72. 
was promoting a limited introduction of international guaranties for the rights of national minorities. ${ }^{4}$ The result of the compromise of the Great Powers was that the Committee for the New States had imposed international protection of racial, religious, and linguistic minorities only to the successor states of the four dissolved empires, with several restrictions that allowed them full control over its implementation without the interference of the Permanent Court for International Justice. ${ }^{5}$

The countries concerned were dissatisfied with the final conclusions and viewed them as a violation of their sovereign rights. The discontent was strengthened by the fact that the international system was imposed by Great Britain and France, two countries with the greatest number of minorities. One of countries concerned was the Kingdom of Serbs, Croats, and Slovenes (Kingdom of the SCS). The protection of minority rights was guaranteed by the Article 51 of the Treaty of Saint-Germain-en-Laye and the Treaty between the Principal Allied and Associated Powers and the Kingdom of the SCS. As far as the Yugoslav side was concerned, Article 51 was one of the most difficult provisions. ${ }^{6}$

The Kingdom of the SCS, together with Romania and Czechoslovakia, formed the Little Entente in 1920-1921. Their alliance became an important part of the French anti-German network of states and the four states were creating new policies in Central Europe based on mutual assistance on different issues, minority rights included. The dynamics of the activities of the three member states differed in the first half of the 1920s. ${ }^{7}$ At first, it was a consequence of limited French support only to Poland and

$4 \quad$ Hilpold, „Minderheitenschutz im Völkerbundsystem“, 166, 167; Thomas Smejkal, Protection in Practice: The Minorities Section of the League of Nations Secretariat, 1919-1934, A Bachelor's Theses, Columbia University, 2010, 15, accessed 4. 1. 2015, https://academiccommons.columbia.edu/doi/10.7916/D8Q52WJZT

5 Giuseppe Motta, Less than Nations: Central-Eastern European Minorities after WWI, Volume I, (Newcastle: Cambridge Scholars Publishing, 2013), 47, 48; Smejkal, Protection in Practice, 12-16, 19; Richard Veatch, "Minorities and the League of Nations", The League of Nations in Retrospect: Proceedings of the Symposium, (Berlin - New York: De Gruyter, 1983), 396.

6 Zoran Janjetović, „Pitanje zaštite nacionalnih manjina u Kraljevini SHS na konferenciji mira u Parizu 1919-1920”, Istorija 20. veka 2/2000, 33-40; Andrej Mitrović, Jugoslavija na konferenciji mira 1919-1920, (Beograd: Zavod za izdavanje udžbenika, 1969), 200-205.

7 Zdeněk Sládek, Malá dohoda 1919-1938: Její hospodářské, politické a vojenské komponenty, (Praha: Karolinum, 2000); Magda Ádám, Richtung Slebstvernichtung: Die Kleine Entente 1920-1938, (Budapest: Corvina, Wien: Österreichischer Bundesverlag, 1988); Milan Vanku, Mala Antanta 1920-1938, (Titovo Užice: IP „Dimitrije Tucović", 1969); Eliza Kampus, Mica Înțelegere, (București: Editura Ştiinţifică, 1968). 
Czechoslovakia. ${ }^{8}$ The gradual building of cooperation between France and the Little Entente - which was based on French-Czechoslovakian collaboration - resulted in Yugoslav and Romanian indifference in discussions on the minority rights in the League of Nations (LoN). No wonder then, that Poland and Czechoslovakia had a leading role in defending the interests of the states with minority obligations in that period. ${ }^{9}$

The most famous case in the disputes over minority rights was sparked by an argument between German and Polish foreign ministers Gustav Stresemann and August Zaleski, in 1928, and culminated in an overall examination of the existing system by the Assembly of the LoN in $1930 .{ }^{10}$ The Yugoslav Ministry of Foreign Affairs (MFA) had estimated that Stresemann's proposal for the formation of the Permanent Commission for Minorities was more contesting the interests of Czechoslovakia than the Kingdom of the SCS and Romania. Although cooperation between France and the Little Entente was at its peak at the time, the two sides had collided on that particular issue. The Little Entente took a mutual stand with Poland and Greece against any introduction of new minority obligations, while France was defending the traditional Great Powers policy of exclusive rights to changing the international order or law. Konstantin Fotić, the Permanent SCS delegate in Geneva examined in detail the issue of protecting minorities only at the beginning of 1929. Foreign Minister Vojislav Marinković profiled himself as the main advocate of the states with mi-

8 The Yugoslav delegation at the Peace Conference was aligning its attitudes with the Romanian and Greek delegates to avoid isolation before the Great Powers. Janjetović, „Pitanje zaštite nacionalnih manjina“, 36.

9 Smejkal, Protection in Practice, 29-31, 40; Weber, „Der Minderheitenschutzes des Völkerbundes", 14; Stanislaw Sierpowski, "Die Stellung Polens zu dem Bestimmungen des Völkerbundes über die nationalen Minderheiten", Friedenssichernde Aspekte der Minderheitenschutzes in der Ära des Völkerbundes und der Vereinten Nationen in Europa, Hrsg. Manfred Mohr, (Berlin-Heidelberg: Springer-Verlag, 1996), 35-37; Sebastian Bartsch, "Erfolge im Schatten der Scheiterns - Das Minderheitenschutzverfahren des Völkerbundes", Friedenssichernde Aspekte der Minderheitenschutzes in der Ära des Völkerbundes und der Vereinten Nationen in Europa, Hrsg. Manfred Mohr, (Berlin-Heidelberg: Springer-Verlag, 1996), 71; Kosta. St. Pavlović, Vojislav Marinković i njegovo doba (1876-1935), knjiga druga, (London: M. Caplin \& Co., 1956), 76, $78,81$.

10 Smejkal, Protection in Practice, 44-50; P. Hilpold, „Minderheitenschutz im Völkerbundsystem“, 176, 177; Bartsch, Minderheitenschutz, 97; Walter Poeggel, “Die Haltung Deutschlands zur Minderheitenfrage", Friedenssichernde Aspekte der Minderheitenschutzes in der Ära des Völkerbundes und der Vereinten Nationen in Europa, Hrsg. Manfred Mohr, (Berlin-Heidelberg: Springer-Verlag, 1996), 58, 59; Christoph M. Kimmich, "Germany and the League of Nations", The League of Nations in retrospect: proceedings of the symposium, (Berlin - New York: De Gruyter, 1983), 121, 145, 146; Veatch, "Minorities and the League of Nations", 377, 378, 380. 
nority obligations during the debate at the XI session of the Assembly of the $\mathrm{LoN}$ in 1930. His tactic was to bring the debate to the crucial question of jurisdiction and threatened the Great Powers with the involvement of the Permanent Court of International Justice, knowing it was the last resort that the Foreign Office and Quay d'Orsay would accept. The result was a conclusion that did not impose new responsibilities to the states with minority obligations. The aftermaths was unsuccessful attempts by Germany Austria, Hungary, and Bulgaria to reopen the debate during 19311932; and Polish Foreign Minister Józef Beck's final decision to settle disputes with Germany on a bilateral level, in $1934 .{ }^{11}$

If Yugoslav politicians had not taken an active role from the very start of the implementation of the minority rights, they were not ignorant of the changed circumstances. The government's first affirmative decision was to form a special department assigned to examine changes in international law and to supervise the implementation of the accepted commitments. The intention was to avoid mechanical enactment of obligations, scrutinize important changes in international law, and prepare the groundwork for the implementation. The department for enactment of international agreements was organized at the presidency of the government, since the first impression was that the minority rights were not an issue for any particular ministry. Changes in the system introduced by the LoN and particular practices had an impact on the Yugoslav politicians to shift the department from the government to the MFA in 1922. The alteration clearly addressed two standpoints. The first was that the Kingdom of the SCS was more interested in benefits for the Yugoslav Diaspora than the rights of ethnic minorities in the Kingdom of the SCS. The second was that the government had realized that the minority rights were used by other countries for political aims. The Yugoslav Diplomatic Service was quite inactive - as far as the LoN was concerned - at first. Until 1927 the Legation in Bern was in charge of communication with Geneva, excluding the interim period from mid-1924 until early 1925. The foreign ministers did not attend the first two sessions of the assembly. Momčilo Ninčić introduced a new practice in 1922 that the foreign ministers were heads of delegations for the sessions of the assembly, and it was applied until Milan Stojadinović took over the MFA in mid-1935. The permanent

11 Срђан Мићић, „Мала антанта и питање мањина пред Друштвом народа 1927-1934. године“, Od Moravy k Moravě III: Z historie česko-srbských vztahů, Editoři: Václav Štěpánek, Ladislav Hladký, Верица Копривица, (Brno: Matice moravská, Maticí srbskou, 2017), 338-348. 
delegation in Geneva was opened shortly in 1924-1925, and finally started operating normally from 1927. Konstantin Fotić was appointed as the permanent delegate during 1927-1929 and 1932-1935,12 while in other periods acting permanent delegates were appointed or duty was entrusted to the plenipotentiary ministers in Bern and Paris. ${ }^{13}$

The largest minority groups in Yugoslavia were Germans, Hungarians, and Albanians. They comprised 1.5 million citizens. ${ }^{14}$ Among them, the Hungarian minority was the most agile in filing complaints to the LoN. Albanian petitions were not a serious challenge for the Yugoslav authorities, since most of the signatories were either on international warrants or were considered as irredentists. The biggest problem was a petition filed by three Albanian catholic priests who had fled from the Kingdom of the SCS, which was on the LoN's agenda during 1930-1931..$^{15}$ The German minority filed only one petition before the LoN in June of 1930 and the discussion continued through 1935 when the Yugoslav authorities decided to fulfill their earlier commitment as a gesture of good will in the period of the Yugoslav-German rapprochement. ${ }^{16}$

During 1921-1938, 35 minority petitions were submitted to the LoN against the Yugoslav authorities, 12 by the Hungarians and 11 by the Bulgarians. ${ }^{17}$ Yet, there was significant disparity in the positions of the two groups, which were based on historical events. The Hungarian minority unlike the Bulgarian - was recognized by the Yugoslav authorities. Hungarians were mostly inhabitants on former Habsburg territories and until 1918 they had held privileged positions compared to the South Slavs, particularly in terms of using their mother tongue, educational opportunities, participation in government, etc. After the breakup of Austria-Hungary and the creation of the Kingdom of the SCS, the Yugoslav authorities had no illusions as to the possible assimilation of the Hungarian minori-

12 Nataša Milićević, „Konstantin Fotić - diplomata od karijere“, Istorija 20. veka, god. XVI, br. 1 (1998), 147, 148, 150, 151.

13 For further reading: Срђан Мићић, од бирократије до дипломатије. Историја југословенске дипломатске службе 1918-1939, (Београд: ИНИС, 2018); Мићић, „Мала антанта и питање мањина“, 329-335.

14 Zoran Janjetović, Deca careva pastorčad kraljeva. Nacionalne manjine u Jugoslaviji 1918-1941, (Beograd: INIS, 2005), 65, 66, 70-82.

15 Arhiv Jugoslavije (Archives of Yugoslavia - AJ), Fond Stalne delegacije pri Društvu naroda - Ženeva (159), kutija 5, fascikla XVI, telegram Kumanudija, Pov. Br. 3840 od 24 aprila 1929; AJ, 159, k. 9, f. 4, Šumenković MID-u, Pov. Br. 59 od 21. januara 1931; Janjetović, Deca careva pastorčad kraljeva, 398-400.

16 Janjetović, Deca careva, 404, 405; Bartsch, Minderheitenschutz, 111, 112.

17 Bartsch, Minderheitenschutz, 104. 
ty into the Slavic majority. ${ }^{18}$ The Hungarian Government had persuaded the Great Powers during the Peace Conference - based on the contemporary complaints of the Hungarian minorities in the successor states to the Dual Monarchy - to introduce supplementary provisions for the protection of minority rights in the Peace Treaty of Trianon. ${ }^{19}$

The major part of the Bulgarian minority had inhabited the Vardar Macedonia, which was for at least two decades an issue of Serbian-Bulgarian dispute and was finally incorporated into the Kingdom of Serbia and later the Kingdom of the SCS. The Yugoslav delegation at the peace conference had tried, unsuccessfully, to exclude that territory from the treaties on the protection of the national minorities. ${ }^{20}$ The lesser part of the Bulgarian minority represented the population of two districts in western Bulgaria, added to the Kingdom of the SCS. Although that territory was not acquired on an ethnic principle, its inhabitants were denied the right to declare themselves as Bulgarians. The same applied to their compatriots in Vardar Macedonia. Only inhabitants born in Bulgaria were allowed to state their ethnic affiliation openly, as the case of the Šalević (Шалев) family indicates. ${ }^{21}$ The Serbian elite considered the Macedonian population as people without a clearly defined ethnic identity and did not recognize them either as Bulgarians or as Macedonians, ${ }^{22}$ but referred to them as "South Serbs." The goal was to create a Serbian national identity among the majority of the population. The Bulgarian petitions submitted to the LoN regarding their position in Vardar and Aegean Macedonia during 1924-1933, were unique cases of a minority that was not recog-

18 Janjetović, Deca careva, 86, 87, 91-94, 97, 121-126.

19 Janjetović, „Pitanje zaštite nacionalnih manjina“, 40, 41.

20 Balkanski ugovorni odnosi 1876-1996. Dvostrani i višestrani međunarodni ugovori i drugi diplomatski akti o državnim granicama, političkoj i vojnoj saradnji, verskim i etničkim manjinama, II tom (1919-1945), prir. Momir Stojković, (Beograd: Službeni list SRJ, 1998), 34-55; Janjetović, „Pitanje zaštite nacionalnih manjina“, 33-40; Mitrović, Jugoslavija na konferenciji mira, 200-204.

21 In the census list for the municipality of Skopje Dimitrije Šalević (Димитър Шалев) entered: in the section "Mother tongue" - "Serbian (Macedonian dialect)", in the section "ethnicity" - "now a Serb". His wife Živa Šalev entered she had Bulgarian nationality and mother tongue. For their daughter Netka Šalević (Недка Шалев) it was entered that her mother tongue was Bulgarian and her nationality "now a Serb". For their son Ivan Šalević (Иван Шалев) it was stated that his mother tongue was Bulgarian while he was of Serbian nationality. Differences were possible, while Dimitar and Ivan were born in Skopje, and Živa and Nedka were born in Sofia and Veliko Trnovo respectively (AJ, 159, k. 41, f. 6 v. d. generalnog političkog direktora MID Dr Pavle Karović Stalnoj delegaciji u Ženevi, Pov. Br. 8017 Reg. Br. Mak. 20-16 od 26. aprila 1930).

22 Janjetović, Deca careva pastorčad kraljeva, 17. 
nized by states, signatories of minority treaties. ${ }^{23}$ The Bulgarian minority asked for consent to open minority schools and conduct religious service in the Bulgarian language. The Yugoslav thesis was that in the state of the South Slavs there was no South Slavic minority, either in terms of race, religion, or language; therefore, South Slavic children attended classes conducted in their mother tongue; while religious services in Slavic Orthodox churches were conducted in Old Slavic, not, in Serbian nor in Bulgarian. ${ }^{24}$

During the first half of the 1920s, the Bulgarian tactic for winning the hearts and minds of the Slavs in Macedonia was based primarily on the actions of the Internal Macedonian Revolutionary Organization (IMRO). The IMRO had maintained authority through guerilla warfare against the local and government authorities and used prevailing influence to instruct the local population on how to vote. It supported the opposition - the Communist Party of Yugoslavia, the Yugoslav Democratic Party (YDP), and the Yugoslav Republican Party - until 1924, but later changed tactics and started to create a network of the Peoples Radical Party's MPs in Macedonia. ${ }^{25}$ During the late 1920s, the tactics had been changed due to a conflict between the IMRO's older and younger generations and successful counteractions of the Yugoslav authorities against guerrilla operations. The guerrilla warfare was superseded by terrorism, and collaboration with the MPs lost its previous importance. ${ }^{26}$ The terrorist actions had

23 Bulgarian minority in Aegean Macedonia was not recognized by the Greek authorities. Jane K. Cowan, "Who's afraid of violent language? Honor, Sovereignty and Claims-Making in the League of Nations", Anthropological Theory, Volume 3, Issue 3 (September 2003), 275; Veatch, "Minorities and the League of Nations" 370, 371.

24 Мићић, „Мала антанта и питање мањина“, 336.

25 Др Милан Ђ. Милојевић, Балканска равнотежа: сећања краљевог дипломате, прир. Милена Павловић, Милан Шећеровић, (Београд: Signature, 1994), 190, 191; Иванъ Михайловъ, Спомени II. Освободителна борба 1919-1924 г., [Louvain], 1965; Иванъ Михайловъ, Спомени III Освободителна борба 1919-1924 г., [Louvain], 1967; Vladan Jovanović, Jugoslovenska država i Južna Srbija 1918-1929: Makedonija, Sandžak, Kosovo i Metohija u Kraljevini SHS, (Beograd: INIS, 2002), 70, 71, 73; Гордана Кривокапић-Јовић, Оклоп без витеза. О социјалним основама и организационој структури Народне радикалне странке у Краљевини Срба, Хрвата и Словенаца (1918-1929), (Београд: ИНИС, 2002), 179-183; Надежда Цветковска, Македонското прашање во југословенскиот парламент меѓу двете светски војни, (Скопје: ИНИ, 2000), 102-105; Костадин Палешутски, Македонското освободително движение след Първа световна война (1918-1924), (София: БАН, 1993).

26 Петър Шанданов, Богатство ми е свободата. Спомени, (София: ИК „Гутенберг“, 2010), 120, 121; Михайловъ, Спомени II; Михайловъ, Спомени III; Dmitar Tasić, "The Institutionalization of Paramilitarism in Yugoslav Macedonia: The Case of the Organization Against the Bulgarian Bandits, 1923-1933", Journal of Slavic Military History, Vol. 32, No. 3 (2019), 408, 409; Jovanović, Jugoslovenska država i Južna Srbija, 176, 196; Иван Т. Ристић, „Бугарска у политици Краљевине Срба, Хрвата и Словенаца 
started on a large scale by the younger generation. Activities of the IMRO and the Macedonian Youth Secret Revolutionary Organization (MYSRO) were prosecuted in two major court proceedings in Resen and Skopje. The assassination of General Mihailo Kovačević led to closing down the Yugoslav-Bulgarian border. The Bulgarian public was more interested in the background to the murders and missing persons' reports of male members of the assassins' families - including the father and brother of Ivan Mihaylov Gavrilov (Иван Михайлов Гаврилов), a member of the Central Committee of the IMRO. ${ }^{27}$

The IMRO and the legal organizations of Bulgarian emigrants in Sofia had seized the opportunity and used those events to draw the attention of the LoN. The trial in Skopje against the members of the MYSRO was used for petitioning against arrests and alleged maltreatment of Bulgarian students and youth in Vardar Macedonia. ${ }^{28}$ Although the Yugoslav authorities did not recognize the Bulgarian minority, the government was obliged to respond to the LoN's section for minorities concerning the data provided in the petitions for specific cases. ${ }^{29}$ The Yugoslav tactic was devised in accordance with the nature of the international organization in Geneva. Since the first task of the LoN was to prevent any future wars, the government noticed that the examination of petitions initiated by the IMRO - which was based in Bulgaria and responsible for the assassinations and bomb attacks on civilian targets on Yugoslav soil - was contra-

(1919-1929)“, (докторска дисертација, Универзитет у Београду, Филозофски факултет, Одељење за историју, 2017), 395-398; Дмитар Тасић, „Војно-политичка акција 'македонствујушчих' у Краљевини СХС/Југославији 1919-1934. године“, Архив. Часопис Архива Југославије, III, 3/2002, 102; Цветковска, Македонското прашање, 107; Костадин Палешутски, Македонското освободително движение 1924-1934, (София: АИ „Проф. Марин Дринов“, 1998); Костадин Палешутски, Македонският въпрос в буржоазна Югославия 1918-1941, (София: БАН, 1983), $112-117,130,131$.

27 Михайловъ, Спомени III, 294-299, 301-310, 341, 343-349; Jovanović, Jugoslovenska država i Južna Srbija, 176, 177, 337; Ристић, „Бугарска у политици Краљевине Срба, Хрвата и Словенаца", 404-407; Dmitar Tasić, "The Macedonian Youth Secret Revolutionary Organisation (MYSRO) 1922-1927: A New Moment in Macedonian Struggle", Geschichte und Region/Storia e regione, 28. Jahrgang, 2019, Heft 1 - anno XXVIII, 2019, n. 1, 36-38.

28 AJ, 159, k. 1, f. IV, generalni politički director MID Milan M. Jovanović stalnom delegatu u Ženevi Konstantinu Fotiću, Pov. Br. 8490 od 9. septembra; Konstantin Fotić ministru inostranih dela Vojislavu Marinkoviću, Pov. Br. 346 od 29. septembra; Fotić MID-u, Pov. Br. 382 od 19. oktobra, Pov. Br. 409 od 24. oktobra 1927; Ристић, „Бугарска у политици Краљевине Срба, Хрвата и Словенаца“, 407, 408.

29 AJ, 159, k. 1, f. IV, Fotić Marinkoviću, Pov. Br. 347 od 29. septembra 1927. 
ry to the fundamental existence of the LoN. ${ }^{30}$ It was argued that the international organization established to preserve peace was supporting one member state's intentions to undermine the internal stability of another member state. The government's reply dismissed the first petition as unacceptable and answered that the provided data was falsified as part of a much broader Bulgarian propaganda campaign against the Kingdom of the SCS. Marinković warned the general secretariat - based on findings of the police investigation which indicated that Bulgarian students were spying on military facilities - not to acquire data on issues that had nothing in common with minority rights. ${ }^{31}$ This tactic achieved its goal and Erik Colban, head of the LoN Minorities Section, took into procedure only one out of six petitions concerning court proceeding in Skopje. His decision was based on the assumption that any broader LoN action would indirectly instigate a new series of terrorist operations. ${ }^{32}$ The government took the matter further and requested that the LoN's Committee of Three should not accept any further petitions initiated by the IMRO. In that issue, Fotić had the full support of Joseph Paul-Boncour, the French member of the Committee. ${ }^{33}$

The same outcome was in the case of a petition regarding the murders of Mihaylo (Михайло Гаврилов) and Hristo Gavrilov (Христо Гаврилов). ${ }^{34}$ The first petition related to the broader issue of civilian murders in the Vardar Macedonia, proved that Ivan Mihaylov Gavrilov's main aim was to seek responsibility for the murder of his closest family members through the LoN. In the following petitions, the lists were neither alphabetical nor chronological - Mihaylo and Hristo Gavrilov were usually named first. ${ }^{35}$ The Yugoslav Government had used aproven tactic and Sir Eric Drummond took same ground as Colban did in cases of the petitions regarding the court proceedings, since he was well aware that the petitioners were cooperating with the IMRO and he did not intend to encourage terrorist actions. The general secretary was seeking a formula not to take

30 Ibid.

31 AJ, 159, k. 1, f. IV Marinković, Pov. Br. 9956 od 14. oktobra; Marinković Fotiću, Pov. Br. 10370 od 24. oktobra 1927.

32 AJ, 159, k. 1, f. IV, Fotić MID-u, Pov. Br. 362 od 12. oktobra, Pov. Br. 366 i 368 od 14. oktobra; pismo Fotića lično za Marinkovića, 3. novembar 1927.

33 AJ, 159, k. 1, f. IV, Fotić Marinkoviću, Pov. Br. 501 od 12. decembra; Fotić MID-u, Pov. Br. 525 od 29. decembra; Fotić Marinkoviću, Pov. Br. 525 od 31. decembra 1927.

34 AJ, 159, k. 1, f. IV, Fotić MID-u, Pov. Br. 457 od 29. novembra; Fotić Marinkoviću, Pov. Br. 459 od 1. decembra 1927.

35 AJ, 159, k. 2, f. I, Fotić lično za Marinkovića, Str. Pov. Br. 153 od 18. marta 1928; AJ, 159, k. 2, f. III, telegram Fotića Marinkoviću, Ženeva, 18. mart 1928. 
in consideration petitions initiated by the IMRO, yet he required a principle decision of the LoN's Committee of Three. Drummond had suggested to Fotić to officially inform him that the Yugoslav Government would not receive any petitions, which were considered as support for the "bandit action," so he could use that statement to ask for the committee's permission to exclude similar petitions. ${ }^{36}$ Marinković advised Fotić and Acting Foreign Minister Ilija Šumenković to decline the petitions on the ground of violent language and to suggest to the MFA discrete cooperation with the Foreign Office (FO) and the Quay d'Orsay. ${ }^{37}$ The LoN General Secretariat decided not to receive similar petitions in procedure; ${ }^{38}$ yet the FO had refused to support the dismissal of petitions en bloc, ${ }^{39}$ and Austin Chamberlain initiated discussion on the Yugoslav stand during the session of the Committee of Three in June of 1928. ${ }^{40}$ With Drummond's support, ${ }^{41} \mathrm{a}$ favorable solution was reached. The committee's conclusion advised the general secretariat to avoid notifying the Yugoslav Government on future petitions initiated by the IMRO due to unreliable sources of presented information and the inauthentic identity of their authors. ${ }^{42}$

The Association of the Macedonian Students Abroad had sent three memorandums to the prominent French leftist concerning their inability to attend classes in their mother tongue. Fotić advised the MFA - after he had held consultations with Albert Thomas, president of the International Labor Organization - to counter it with unofficial propaganda. He proposed that the Yugoslav Association for the League of Nations (YALN) - which had close ties with the MFA ${ }^{43}$ - should publish a brochure on the

36 AJ, 159, k. 2, f. I, Fotić lično za Marinkovića, Str. Pov. Br. 159 od 19. marta 1928; AJ, 159, k. 2, f. III, telegram Fotića Marinkoviću, Ženeva, 19. mart 1928.

37 AJ, 159, k. 2, f. I, Fotić zastupniku ministra inostranih dela Iliji Šumenkoviću, Str. Pov. Br. 159 od 19. marta; telegram Šumenkovića, Str. Pov. Br. 86 od 20. marta; Fotić Šumenkoviću, Str. Pov. Br. 162 od 20. marta; telegram Šumenkovića, Str. Pov. Br. 88 od 21. marta; Fotić poslaniku u Parizu Miroslavu Spalajkoviću, Str. Pov. Br. 232 od 26. aprila; Fotić poslaniku u Londonu Đorđu Đuriću, Str. Pov. Br. 234 od 26. aprila 1928; AJ, 159, k. 2, f. III, telegram Marinkovića Fotiću, Arv, 19. mart 1928.

38 AJ, 159, k. 2, f. I, Fotić lično za Marinkovića, Pov. Br. 198 od 11. aprila 1928; AJ, 159, k. 44, f. 10, Fotić MID-u, Pov. Br. 241 od 30. aprila 1928.

39 AJ, 159, k. 1, f. I C, Howard Smith to the Minister G. Diouritch, 23 March; Đurić Šumenkoviću, Pov. Br. 248 od 23. aprila; Đurić Fotiću, Pov. Br. 250 od 18. maja; savetnik Poslanstva u Londonu Pavle Karović Fotiću, Pov. Br. 337 od 29. maja 1928.

40 AJ, 159, k. 1, f. Fotić lično za Marinkovića, Str. Pov. Br. 321 od 5. juna 1928.

41 AJ, 159, k. 41, f. 1 Fotić lično za Marinkovića, Pov. Br. 333 od 5. juna 1928.

42 AJ, 159, k. 3, f. X Fotić lično za Marinkovića, Pov. Br. 337 od 7. juna; AJ, 159, k. 41, f. 1 Fotić MID-u, Pov. Br. 349 od 10. juna 1928.

43 Members of the YALN were proposed and selected in close collaboration between the president of YALN, the PM and ministers. AJ, Zbirka Vojislava Jovanovića - Ma- 
schools in the Vardar Macedonia with data on the political goals of the Bulgarian student and youth organizations. The aim was to avoid any government responsibility and neutralize Bulgarian propaganda. ${ }^{44}$ Fotićs proposal was accepted and the MFA distributed the YALN brochure Bulgarians and Yugoslavs during 1928. ${ }^{45}$ According to the Đorđe Đurić, the plenipotentiary minister in London, it was well received by the FO and the British public. ${ }^{46}$ This was an important aspect for the MFA since the Balkan Committee in London - known for its pro-Bulgarian agendas - had filed a petition on terror against the Bulgarian minority in the Kingdom of the SCS in mid-1928, which was backed by Stjepan Radić, the leader of the Croatian Peasant Party. ${ }^{47}$ His support meant that one Yugoslav MP and former minister was recognizing the Bulgarian minority, and indirectly implied that the party members might take the same stand. The Yugoslav Government could not use the committee's conclusion to deny answers to the petition or proclaim it as Bulgarian irredentist propaganda, since the Balkan Committee in London was not in any way supporting terrorist actions and the petition was backed by Radić. Marinković had instructed the MFA to collect information on the presented data and to submit the official answer. ${ }^{48}$ The Yugoslav authorities took four months to prepare a reply. ${ }^{49}$ Following Drummond's proposal, the French and the British representatives were chosen - along with himself - as members of the Committee of Three. The committee did not recognize the existence of the Bulgarian minority in the Vardar Macedonia and therefore did not discuss any implemen-

ramboa (335), k. 85, f. 4, pismo predsednika Jugoslovenskog udruženja za Društvo naroda Jovana Žujovića predsedniku Ministarskog saveta Milenku Vesniću, 5. (18) septembar 1920.

44 Konstantin Fotić advised the MFA close collaboration not only with the YALN, but also with university professors which were familiar with counter propaganda versus Bulgaria. AJ, 159, k. 1, f. IV, Fotić Marinkoviću, Pov. Br. 445 od 2. novembra 1927.

45 AJ, 159, k. 2, f. I, generalni politički direktor MID-a stalnom delegatu u Ženevi, Pov. Br. 4699 od 26. aprila 1928; AJ, 159, k. 2, f. II, šef II Političkog odeljenja GPD MID stalnom delegatu, Br.180 od 29. jula 1928.

46 AJ, 159, k. 1, f. I, Đurić Šumenkoviću, Pov. Br. 248 od 23. aprila 1928.

47 AJ, 159, k. 3, f. XVII, Fotić MID-u, Pov. Br. 439 od 14. jula 1928.

48 AJ, 159, k. 3, f. XVII, Fotić MID-u, Pov. Br. 562 od 18. septembra 1928.

49 AJ, 159, k. 3, f. XVII, Fotić lično za Marinkovića, Pov. Br. 450 od 28. jula; telegram Marinkovića, Pov. Br. 8951 od 28. jula; telegram Šumenkovića, Pov. Br. 10196 od 26. avgusta; Fotić MID-u, Pov. Br. 562 od 17. septembra; telegram Šumenkovića, Str. Pov. Br. 252 od 19. septembra; Fotić MID-u, Pov. Br. 580 od 25. septembra; telegram Marinkovića, K. Str. Pov. Br. 252 od 18. novembra; Fotić MID-u, Pov. Br. 666 od 19. novembra; telegram Marinkovića, Pov. Br. 251 od 20. novembera 1928. 
tation of minority treaties in that particular case..$^{50}$ Yet, that was the first time that the Yugoslav authorities had to deal seriously with the Bulgarian petitions before the LoN. According to the preserved archival records, it seems that the MFA's officials were concerned for the first time in examining in detail the issue of minority petitions. On 3 January 1929, the MFA asked Fotić to send all documents concerning the LoN's procedures for minority petitions from the previous 10 years alongside with the most important files on the Balkan Committee's petition. ${ }^{51}$ Sudden interest for minority issues was provoked by the Stresemann-Aleski dispute. Fotić advised Acting Foreign Minister Konstantin Kumanudi to take a more active approach, since the previous rejection to take petitions into consideration was misinterpreted in Geneva as an indirect acknowledgment of guilt. ${ }^{52}$

The agitated atmosphere created by the minority issue prompted a second round of Bulgarian petitions. Drummond held the previous ground and did not take into consideration petitions raising question of the existence of the Bulgarian minority in the Kingdom of the SCS. ${ }^{53} \mathrm{He}$ was processing only petitions concerning specific cases. The MFA used previous experience and was prepared to examine the petitions in greater detail. The main tactic was not changed and the discussion was still focused on the conditions of receivability. ${ }^{54}$ Nevertheless, the biggest chal-

50 AJ, 159, к. 3, f. VI, Fotić MID-u, Pov. Br. 717 od 12. decembra; telegram Marinkovića, Pov. Br. 13742 od 12. decembra; Fotić MID-u, Pov. Br. 727 od 14. decembra 1928; AJ, 159, k. 3, f. XVII, Fotić MID-u, Pov. Br. 704 od 6. decembra 1928; AJ, 159, k. 41,f. 1, Fotić GPD-u MID-a, Pov. Br. 753 od 21. decembra 1928.

51 AJ, 159, k. 5, f. IX, generalni politički director MID Stanoje Pelivanović Stalnoj delegaciji, Pov. Br. 90 od 3. januara; Fotić GPD-u MID-a, Pov. Br. 14 od 22. januara 1929; AJ, 159, k. 5, f. XXVI, Pelivanović Stalnoj delegaciji, Pov. Br. 14160/28 od 3. januara; Fotić GPD-u MID-a, Pov. Br. 13 od 22. januara 1929.

52 AJ, 159, k. 5, f. IX, telegram zastupnika ministra inostranih dela Konstantina Kumanudia, Pov. Br. 445 od 19. januara; Fotić MID-u, Pov. Br. 23 od 19. januara; Fotić Kumanudiu, Pov. Br. 24 od 20. januara 1929; AJ, 159, k. 5, f. XXVI, Pelivanović Stalnoj delegaciji, Pov. Br. 14160/28 od 3. januara 1929.

53 AJ, 159, k. 5, f. XXVI, Fotić MID-u, Pov. Br. 128 od 2. marta 1929.

54 AJ, 159, k. 4, f. III, Stalna delegacija u Ženevi GPD-u MID-a, Pov. Br. 748 od 29. decembra 1929; AJ, 159, k. 41, f. 2, Fotić MID-u, Pov. Br. 229 od 22. marta; generalni politički director MID-a Konstantin Fotić poslaniku u Bernu Iliji Šumenkoviću, Pov. Br. 4955 od 24. maja; telegram Marinkovića, Pov. Br. 6826 od 15. jula; Fotić poslanstvima u Parizu, Londonu i Rimu i Stalnoj delegaciji u Ženevi, Pov. Br. 8459 od 12. avgusta; pomoćnik ministra inostranih dela Lujo Bakotić Stalnoj delegaciji u Ženevi, Pov. Br. 9068 od 23. avgusta; Šumenković MID-u, Pov. Br. 553 od 24. avgusta; telegram i pismo Kumanudia Šumenkoviću, Pov. Br. 9401 od 27. avgusta; Marinković Šumenkoviću, Pov. Br. 118 od 28. avgusta; Šumenković Marinkoviću, Pov. Br. 575 od 29. avgusta 1929. 
lenge for the Yugoslav authorities concerning the Bulgarian petitions was on the horizon.

The signatories of the new petition were Dimitrije Šalević, the former vice-president of the Skopje municipality, and Dimitrije Ilić (Димитър Илиев), a former judge in Veles. It was dated in Skopje in December of 1929, and filed in Geneva in January of 1930. Two weeks later, Gligorije Anastasijević (Григор Анастасов Кюркчиев), former MP and member of the board of the YDP, registrated himself as the third signatory. ${ }^{55}$ The Yugoslav Government faced a significantly different situation. For the first time, the petitioners' claims on the Bulgarian minority had greater credibility since they were citizens of Macedonia and they were elected either by the local population or appointed by the state institutions during the 1920s. The Yugoslav Government had to take a contemplative approach, which instigated a change of tactics. The petition could not be rejected on the ground of the Bulgarian irredentist propaganda. The new strategy was devised to personally discredit all three signatories. The MFA was collaborating closely with the other Yugoslav authorities. ${ }^{56}$ The interior ministry took only five days to gather data on Shalev and Iliyev. The official report described them as deceptive persons who were seeking only personal gains. ${ }^{57}$ Milan Milojević, a prominent member of the YDP expressed a similar view on Anastasov, probably only to diminish the latter's importance for the party in Vardar Macedonia. ${ }^{58}$ The three petitioners had close collaboration with the IMRO from the start, most probably through personal a friendship between Dimitar Shalev and Yordan Gyurkov (Йордан Христов Гюрков). The organization provided financial and logistical support. ${ }^{59}$ The MFA confirmed information on that matter in May of $1930 .{ }^{60}$

55 От Скопие до Женева. Димитър Шалев - защитник на малцинствата в Обществото на народите, съставител Димитър Митев, (София: Логис, 2012), 63-67, 73-75, 113.

56 AJ, 159, k. 8, f. 15/II, sekretar Stalne delegacije u Ženevi Branko Dimić PO-u MIP-a, Pov. Br. 1229/1930 od 24. januara; v. d. načelnika PO MIP Pavle Karović Stalnoj delegaciji, Pov. Br. 2565 od. 13. februara 1930; AJ, Fond Ministarstva inostranih poslova Kraljevine Jugoslavije (334), kutija 178, jedinica opisa 501, listovi 437, 438.

57 От Скопие до Женева, 80-82, 98, 99, 117.

58 Milojević was evidently so irritated by the course of events that he did not even mention Atanasov by name in his memoirs. Милојевић, Балканска равнотежа, 190, 191.

59 For further reading: От Скопие до Женева, passim.

60 AJ, 159, k. 44, f. 15/III, Karović poslanstvima u Sofiji i Tirani, Konzulatu u Korči i Stalnoj delegaciji u Ženevi, Pov. Br. 10321 Reg. Br. Bu.-8.00 od 31. maja; Karović Ministarstvu unutrašnjih poslova i Stalnoj delegaciji u Ženevi, Pov. Br. 11437 od 12. juna 1930. 
The Yugoslav diplomatic, police, and military services had a watchful eye on the contacts between these three petitioners, on the one hand, and the IMRO, the Croatian, Albanian, and Montenegrin political emigration, on the other hand. ${ }^{61}$ The issue was particularly sensitive as some gathered information suggested potential cooperation in terrorist actions. ${ }^{62}$ According to preserved archival sources, it seems that the discovery of connections between the three petitioners and the IMRO was crucial for the failure of their action in Geneva. ${ }^{63}$ The tactic was successful and the Kingdom of Yugoslavia no longer faced dangerous accusations.

The petition had two side effects, which had concerned the Yugoslav authorities. The first was a new round of minority petitions signed by the different Bulgarian organizations. ${ }^{64}$ The second, more important, was the fact that Drummond had asked the LoN's Section for Minorities to write a report on Serbian-Bulgarian relations and the so-called "Macedonian question." The report did not favor the Yugoslav side, since it was based primarily on information from the British, Austrian, and Hungarian press, and was referring to the existence of an undefined Macedonian minority while recommending autonomous administration for Vardar, Aegean, and Pirin Macedonia. ${ }^{65}$ Nevertheless, neither of those two side effects had any impact on the Yugoslav positions in the LoN. The great debate on the system for protection of minority rights had a grand finale on the XI Session of the Assembly in 1930. The Yugoslav Diplomatic Service had far less difficulties handling the subsequent petitions signed by Sha-

61 AJ, 159, k. 44, f. 15/III, Karović Stalnoj delegaciji, Pov. Br. 7667 i 7911 od 26. aprila; Fotić Stalnoj delegaciji, Pov. Br. 8496 Reg. Br. Mav 20-16 od 7. maja; Karović Stalnoj delegaciji, Pov. Br. 11437 od 12. juna; otpravnik poslova u Bernu Sreten Stojaković Stalnoj delegaciji, Pov. Br. 224 od 21. jula; otpravnik poslova u Ženevi Ivo Andrić PO-u MIP-a, Pov. Br. 702 i 703 od 30. jula; telefonski izveštaj Šumenkovića, Pov. Br. 763 od 19. avgusta; Marinković Stalnoj delegaciji, Pov. Br. 16535 od 20. avgusta 1930; От Скопие до Женева, 131.

62 AJ, 159, k. 44, f. 15/III, šef I odeljenja GPD MID Dragomir Ž. Kasidolac Stalnoj delegaciji u Ženevi, Pov. Br. 12168 Reg. Br. Bu.-8.00 od 25. juna 1930.

63 AJ, 159, k. 9, f. 2, poslanik u Bernu i stalni delegat u Ženevi Ilija Šumenković GPD-u MID-a, Pov. Br. 182 od 15. marta 1931.

64 AJ, 159, k. 7, f. 15/I, Karović Stalnoj delegaciji, Pov. Br. 4864 od 13. marta; Stalna delegacija MID-u, Pov. Br. 316 od 23. aprila 1930; AJ, 159, k. 9, f. 2, Karović Stalnoj delegaciji, Pov. Br. 17239, Reg. Br. Mav. 1 od 24. avgusta 1931; AJ, 159, k. 9, f. 6, Stalna delegacija Kumanudiu, Pov. Br. 86 od 30. januara 1931; AJ, 159, k. 44, f. 15/III, Karović Stalnoj delegaciji, Pov. Br. 7667 od 26. aprila; Fotić Stalnoj delegaciji, Pov. Br. 9924 od 26. maja; telegram Šumenkovića MID-u, 19. septembar 1930.

65 AJ, 159, k. 44, f. 15/III, Andrić Marinkoviću, Pov. Br. 701 od 28. jula 1930. 
lev, Iliyev, and Anastasov. ${ }^{66}$ Finally, Iliyev had accepted cooperation with the Yugoslav authorities against Shalev and Anastasov in 1932. The former had denounced publicly his previous cooperation with the latter and dismissed the truthfulness of all the allegations stated in their petitions and in their correspondence with foreign organizations and the press. ${ }^{67}$

Unlike the Bulgarian petitions, the Yugoslav authorities were convinced that the Hungarian minority's charges were mostly designed by the official institutions in Budapest. The Hungarian Government was largely relying on international propaganda during the 1920s. Complaints were not filed in Geneva as it was estimated that the LoN was favoring the victorious over the defeated nations. Only one petition was filed at the beginning of the 1920s and it concerned one personal case. Even the Hungarian diplomats in Belgrade were reluctant to support minority requests for addressing to the LoN. One of the reasons for the Hungarian Diplomatic Service's passivity was dissatisfaction with the organizational skills of the Hungarian minority in the Kingdom of the SCS. After King Aleksandar had established a dictatorial regime their approach changed. ${ }^{68}$

Imre Prokopy, the general secretary of the dissolved Hungarian Party, started his action in Geneva. He sent 20 petitions and supplements from November of 1929 through February of 1933. The Government in Budapest supported him only after it became clear that he could not achieve the stated goals. Complaints were concerning issues of general interest for the Hungarian minority: newly introduced educational policies in schools, dismissed Hungarian teachers, banned the usage of the Hungarian language in official communication, and the government's attitude toward sports, cultural, and other Hungarian associations. ${ }^{69} \mathrm{Al}-$ though the MFA was convinced that he was a member of the League for Revision, ${ }^{70}$ it did not rejected petitions based on procedure of receivabil-

66 AJ, 159, k. 9, f. 6, Stalna delegacija Kumanudiu, Pov. Br. 86 od 30. januara 1931; AJ, 159, k. 18, f. 17/I, Andrić MID-u, Pov. Br. 44 od 16. januara; Karović Stalnoj delegaciji, Pov. Br. 1034, Reg. Br. Mav 5 od 20. januara 1931.

67 AJ, 159, k. 46, f. 4-1, generlani konzul u Ženevi N. S. Petrović Stalnoj delegaciji u Ženevi, K. Str. Pov. Br. 109 od 21. oktobra 1932.

68 Janjetović, Deca careva, 402; Enike A. Šajti, Mađari u Vojvodini 1918-1947, (Novi Sad: Forum, 2010), 82, 85, 87, 89; Nándor Bardi, Ferenc Eiler, "Territorial revision and minority protection in Hungarian politics", Minority Hungarian Communities in the Twentieth Century, eds Nándor Bardi, Csilla Fedinec, Lászlo Szarka, (New York: Columbia University Press, 2011), 131-137.

69 Janjetović, Deca careva, 402; Šajti, Mađari u Vojvodini, 83, 87.

70 AJ, 159, k. 9, f. 3, Kasidolac Stalnoj delegaciji, Pov. Br. 14993, Reg. Br. Manj. 20-05 od 2. avgusta i Pov. Br. 16305 od 25. avgusta 1930. 
ity and answered to most of the filed accusations. The Yugoslav authorities rejected part of Prokopy's petitions - most probably drawing on their experience with the Bulgarian petitions - on the grounds of his residency in Hungary. The presented cases were countered with contrasting data or were represented as isolated problems detached from the general trends. In cases of schools and teachers, statistical data was used in such a manner that Yugoslav theses could be proved easily. The question of using the official and minority languages was justified by the necessity for communication between the municipal clerks and the local population. ${ }^{71}$ It was convenient for the Yugoslav authorities to denounce Prokopy as a revisionist since his residence was in Hungary, regardless of the fact that he was the former general secretary of the Hungarian Party in the Kingdom of the SCS. ${ }^{72}$ Other Hungarian petitioners submitted specific cases, which were unimportant for the Kingdom of Yugoslavia and the LoN, most were rejected by the Committee of Three. ${ }^{73}$ According to the interior ministry, all the petitioners were Hungarians who had refused to pledge loyalty to the new homeland and left the Kingdom of the SCS before $1928 .^{74}$

The Bulgarians and Hungarians tried - in addition to addressing the LoN - to indirectly influence the diplomats in Geneva through the International Federation of League of Nations Societies and the European Congress of Nationalities. The Federation had close relations with the LoN General Secretariat and its work was influenced by the French repre-

71 AJ, 159, k. 9, f. 3, Karović Stalnoj delegaciji, Pov. Br. 1209 od 24. januara i Pov. Br. 1625 od 1. februara 1930; AJ, 159, k. 14, f. 1, Dimić GPD-u MID-a, Pov. Br. 526 od 5. juna; MID Stalnoj delegaciji, Pov. Br. 11105 od 12. juna; Fotić Stalnoj delegaciji, Pov. Br. 12057 od 5. jula; Dimić Stalnoj delegaciji, Pov. Br. 934 od 15. oktobra; Kasidolac Stalnoj delegaciji, Pov. Br. 23956, Reg. Br. Mav 20-05 od 12. decembra 1930; AJ, 159, k. 14, f. 2, Šumenković GPD-u MID-a, Pov. Br. 427 od 8. maja; Fotić Stalnoj delegaciji, Pov. Br. 12035 od 12. jula 1930; AJ, 159, k. 9, f. 3, Fotić Stalnoj delegaciji, Pov. Br. 12662 od 9. jula i Pov. Br. 21208 Reg. Br. Manj 20-05 od 21. oktobra 1930; AJ, 195, k. 14, f. 5, Karović Stalnoj delegaciji, Pov. Br. 12938, Reg. Br. Manj. 20-05 od 30. septembra; Fotić Stalnoj delegaciji, Pov. Br. 21781 od 8. i decembra i Pov. Br. 23316 Reg. Br. Manj 20-05 od 10. novembra 1930; Janjetović, Deca careva, 403; Šajti, Mađari u Vojvodini, 89.

72 Šajti, Mađari u Vojvodini, 87.

73 The only success was temporarily improvement of school teaching. AJ, 159, k. 9, f. 6, Šumenković MID-u, Pov. Br. 441 od 6. aprila 1931; Janjetović, Deca careva pastorčad kraljeva, 404.

74 AJ, 159, k. 9, f. 3, Karović Stalnoj delegaciji, Pov. Br. 19595, Reg. Br. Manj. 20-05 od 14. oktobra 1930; AJ, 159, k. 14, f. 6, Fotić Stalnoj delegaciji, Pov. Br. 14791, Reg. Br. Mav. 16 od 16. jula 1931. 
sentatives. ${ }^{75}$ The congress had a partial impact since their annual forums were held before sessions of the LoN assembly and council, yet its work was based on the German perception of nations and ethnicities. Since its foundation in 1925 - in which representatives of the Hungarian minorities took part - it had tacit support from Hungarian PM István Bethlen for tackling contemporary minority issues. Close German-Hungarian-Jewish cooperation resulted in their full control over the Congress until $1933 .{ }^{76}$ It seems that the Yugoslav Foreign Service was not troubled with the action in the ranks of the Federation, ${ }^{77}$ which was under French influence. The case of the congress was quite different.

The Yugoslav delegations had as significant position as Josip Vilfan $^{78}$ - representative of the Slovene minority in Italy - was president of

75 The Federation was founded in Geneva in 1919 as a reaction to the disappointing draft of the LoN's Covenant. It was acting on self-initiative and avoided to be patronised by the diplomats or the LoN. The French Association had a dominant position. The Federation had started to advocate forming of the Permanent Minority Committee in the ranks of the LoN 1928. For further reading: Jean-Michel Guieu, "La SDN et ses organisations de soutien dans les années 1920. Entre promotion de l'esprit de Genève et volonté d'influence", Relations Internationales, vol. 151, no. 3 (2012), 1123.

76 The German MFA had been reluctant at first to the idea of the Congress - regardless to fact it was founded on initiative of German minorities - and later did take full control over the Congress as the instrument for promoting pan-German ideas. Jewish delegates declined further cooperation after 1933. The Congress was dealing with four areas of minority issues: 1) the work and procedures of the LoN, 2) policies of the states with minority obligations, 3) cultural autonomy, 4) national and supranational cooperation among members of the Congress; and it existed till 1938. Xosé M. Núñez Seixas, “¿Autodeterminación o autonomía cultural? Debates ideológicos en el congreso de nacionalidades Europeas (1925-1939)", Hispania, Vol. 58, Núm. 3 (1998), 1115-1118, 1121-1130; Ferenc Eiler, "International Minority defense system: The League of Nations", Minority Hungarian Communities in the Twentieth Century, eds Nándor Bardi, Csilla Fedinec, Lászlo Szarka, (New York: Columbia University Press, 2011), 98, 99; Ferenc Eiler, "Edle Vorhaben vs. politisches Kalkül. Tätigkeit des Europäischen Nationalitätenkongresses vor und hinter den Kulissen (1925-1938)", Öt Kontinens, az Új- és Jelenkori Egyetemes Történeti Tanszék tudományos közleményei, No 2012/1, 13-19.

77 AJ, 159, k. 5, f. XXVI, Pelivanović Fotiću, III Str. Pov. Br. 13 od 28. januara i II Pov. Br. 484 od 5. februara 1929.

78 Josif Vilfan was born in Slovenian family in Trieste in 1878. He was educated in Trieste, Dubrovnik and Vienna. Vilfan started his professional career in the law office of Dr. Matko Laginja, the later Croatian ban. Later he had established law office in Trieste, and started his national and political work in 1906 . He was elected representative of Slovene minority in municipality of Trieste from 1909, president of "Edinost" from 1910, and Italian MP from Trieste during 1921-1928. Vilfan emigrated from Italy in 1928, after conflict with Benito Mussolini. He started his international career as a member of the Committee for the minority and colonial issues of the Interparliamentary Union in 1923. Vilfan's residency was in Vienna 1928-1939, and during 
the Congress, and the Yugoslav minorities from Austria and Italy were participating in founding the Congress. ${ }^{79}$ His group was closely collaborating with the MFA and the Permanent Delegation in Geneva. ${ }^{80}$ They could not count on help from Czechoslovakia or Poland since their delegates stopped participating in $1927 .{ }^{81}$ The Hungarian minorities had demonstrated that they were concerned more with revisionism than with their rights, yet for them the Congress had lost its importance during the IV annual forum, in 1928. Geza Süllo - who was regularly voted as one of the vice-presidents - had a very low opinion of the efficiency of the Congress. The Yugoslav authorities had been preventing the participation of former Hungarian minority representative Leo Deak in the Congress since 1929, and it became clear that the German and the Hungarian minorities in the Kingdom of the SCS had different agendas. ${ }^{82}$

The Yugoslav representatives on the V and the VI annual forum were struggling against propaganda of the Bulgarian and Hungarian minorities - in the midst of the discussion on minority rights in the LoN who were using meetings to distribute petitions filed in the LoN. The Yugoslavs had yet another important task, to prevent he participation of Shalev, Atanasov, and Iliyev. However, they had failed to prevent the recognition of the Bulgarian minority in Macedonia. ${ }^{83}$ As a reaction, the most activate petitioners were trying to create a Bulgarian-Hungarian group and suppress Vilfan's influence. The dispute took place in the wider framework of the German-Italian competition for control of minority issues. The Yugoslav minority representatives were closely cooperating with the Germans, while the Bulgarian-Hungarian group was seeking support from

most of that period he was president of the Congress. Later he had changed residency and moved to Belgrade. „Др. Јосип Вилфан“, Narodna odbrana, Br. 40, God. III, 30. septembar 1930; 654, 655; Eiler, "Edle Vorhaben", 16, 25.

79 Seixas, “¿Autodeterminación o autonomía cultural?, 1115, 1116; Eiler, "Edle Vorhaben”, 16.

80 Vilfan and the Yugoslav delegates from Italy and Austria were instructed by the Foreign Minister and their expenditures were funded by the MFA. AJ, 159, k. 41, f. 2, Fotić Kumanudiu, Pov. Br. 580 od 31. avgusta 1929; AJ, 159, k. 7, f. 8, telegram Marinkovića, Pov. Br. 16777 od 27. avgusta 1930.

81 Eiler, "Edle Vorhaben", 18.

82 Šajti, Mađari u Vojvodini, 86, 87; Eiler, "Edle Vorhaben", 20.

83 AJ, 159, k. 41, f. 2, Fotić Kumanudiu, Pov. Br. 580 od 31. avgusta 1929; AJ, 159, k. 7, f. 8, Šumenković MID-u, Pov. Br. 828 od 4. septembra 1930; izveštaj „Šesti Kongres nacionalnih manjina. Odžran u Ženevi, 3-5 IX 1930.". Bulgarian representatives from Yugoslavia were participating on the annual forums held in 1929, 130, 1933 and 1934. Eiler, "Edle Vorhaben vs. politisches Kalkül”, 24. 
the Italians. ${ }^{84}$ Prokopy, Shalev, and Atanasov formed the Association for the protection of ethnic minorities in Yugoslavia, in May of 1931. Their intention was to forge a minority organization as an alternative to the Congress, and their main goal was to maintain the LoN's interest in their cases. The new tactic had no effect on the Yugoslav strategy since the main discussion on the minority protection was finished in the LoN in 1930. Contrary to the three petitioners' intentions, their official cooperation became a useful argument for the Yugoslav Permanent Delegation which could easily emphasize that there was no difference between those signatories backed by terrorists and those who acted as concerned individuals. ${ }^{85}$ Likewise, their action had an insignificant impact on the VII annual forum of the Congress, since Vilfan had been collaborating very closely with the Jewish and German delegates. ${ }^{86}$

\section{Summary}

From the Yugoslav viewpoint the crucial difference in forming particular tactics were measures employed by the Bulgarian and the Hungarian minorities during the Interwar Period. Although the Hungarian minority was recognized - and in that sense had represented one of the three largest minority groups - it was not affiliated with illegal activities such as guerilla warfare or terrorism. Therefore, their petitions represented a minor menace compared to the Bulgarian case. Yugoslavia's inactivity in minority rights was evident until the Stresemann-Zaleski dispute had opened a full discussion on the international system. It sparkled action led by Marinković and supported wholeheartedly by Fotić. Also, the discussion initiated series of Hungarian and Bulgarian petitions. The main Yugoslav strategy in the Bulgarian case was to prove the connection between the minority complaints and terrorist operations conducted on Yugoslav soil. The main challenge was the petitions signed by Shalev, Anastasov, and Iliyev, as former official representatives of the local population. The Yugoslav authorities had to change their course of action and

84 AJ, 159, k. 9, f. 6, Karović Stalnoj delegaciji, Pov. Br. 7802, Reg. Br. Mav. 5 od 24. aprila; Kasidolac Stalnoj delegaciji, Pov. Br. 8244, Reg. Br. Manj. 5 od 30. aprila 1931.

85 AJ, 159, k. 9, f. 3, Karović Stalnoj delegaciji, Pov. Br. 11069, Reg. Br. Mađ. 6-1 od 8. juna 1931; AJ, 159, k. 14, f. 7, Stalna delegacija Fotiću, Pov. Br. 636 od 10. juna 1931; AJ, 159, k. 9, f. 6, Dimić GPD-u MID-a, Pov. Br. 452 od 22. maja 1931; От Скопие до Женева, 437, 438, 442, 443, 448.

86 AJ, 159, k. 9, f. 2, načelnik PO MIP Ivan Vukotić Stalnoj delegaciji, Pov. Br. 17939 od 8. septembra 1931; AJ, 159, k. 9, f. 6, Dimić PO-u MIP-a, Pov. Br. 919 od 2. septembra 1931. 
focus on discrediting petitioners rather than proving their allegiance to the IMRO. Nevertheless, Iliyev's public denunciations on the cooperation between the Bulgarian petitioners and terrorist organization had its impact on countering the Bulgarian-Hungarian activities through the European Congress of Nationalities.

\section{Sources and Literature}

- Ádám, Magda. Richtung Slebstvernichtung: Die Kleine Entente 1920-1938. Budapest: Corvina, Wien: Österreichischer Bundesverlag, 1988.

- $\quad$ Aldeman, David A. A Shattered Peace. Versailles 1919 and the Price We Pay Today. Hoboken: Wiley, 2008.

- Bardi, Nándor, Ferenc Eiler. "Territorial Revision and Minority Protection in Hungarian politics". Minority Hungarian Communities in the Twentieth Century, eds Nándor Bardi, Csilla Fedinec, Lászlo Szarka. New York: Columbia University Press, 2011.

- $\quad$ Bartsch, Sebastian. Minderheitenschutz in der internationalen Politik. Völkerbund und KSZE/OSZE in neuer Perspektive. Opladen: Westdeutscher Verlag, 1995.

- Bartsch Sebastian. "Erfolge im Schatten der Scheiterns - Das Minderheitenschutzverfahren des Völkerbundes". Friedenssichernde Aspekte der Minderheitenschutzes in der Ära des Völkerbundes und der Vereinten Nationen in Europa, Hrsg. Manfred Mohr. Berlin-Heidelberg: Springer-Verlag, 1996.

- Бибо, Иштван. Беда малих источноевропских држава. Сремски Карловци - Нови Сад: ИК Зорана Стојановића, 1996.

- $\quad$ Cowan, Jane K. “Who's Afraid of Violent Language? Honor, Sovereignty and Claims-Making in the League of Nations". Anthropological Theory, Volume 3, Issue 3, September 2003. doi: 10.1177/14634996030033002

- $\quad$ Cvetkovska, Nadežda. Makedonskoto prašanje vo jugoslovenskiot parlament megu dvete svetski vojni. Skopje: INI, 2000. (cyrillic)

- Dvostranii višestrani međunarodniugovori idrugidiplomatskiaktio državnim granicama, političkoj i vojnoj saradnji, verskim i etničkim manjinama, II tom (1919-1945), prir. Momir Stojković. Beograd: Službeni list SRJ, 1998.

- Eberhardt, Piotr. Ethnic Groups and Population Changes in Twentieth-Century Central-Easter Europe: History, Data and Analysis. London - New York: Routledge, 2015. ${ }^{2}$

- $\quad$ Eiler, Ferenc. "International Minority Defense System: The League of Nations". Minority Hungarian Communities in the Twentieth Century, eds Nándor Bardi, Csilla Fedinec, Lászlo Szarka. New York: Columbia University Press, 2011.

- Eiler, Ferenc. "Edle Vorhaben vs. politisches Kalkül. Tätigkeit des Europäischen Nationalitätenkongresses vor und hinter den Kulissen (19251938)". Öt Kontinens, az Új- és Jelenkori Egyetemes Történeti Tanszék tudományos közleményei, No 2012/1. 
- $\quad$ Fiš, Jerg. Pravo naroda na samoopredeljenje. Obuzdavanje jedne iluzije. Beograd: Albatros plus, 2013.

- $\quad$ Guieu, Jean-Michel. "La SDN et ses organisations de soutien dans les années 1920. Entre promotion de l'esprit de Genève et volonté d'influence". Relations Internationales, vol. 151, no. 3, 2012. doi: 10.3917/ri.151.0011

- Hilpold, Peter. „Minderheitenschutz im Völkerbundsystem“. Zur Entstehung des modernen Minderheitenschutzes in Europa. Handbuch der europäischen Volksgruppen, Band 3, Hrsg. Christoph Pan, Beate Sibylle Pfeil. Wien - New York: Springer, 2006.

- Janjetović, Zoran. „Pitanje zaštite nacionalnih manjina u Kraljevini SHS na konferenciji mira u Parizu 1919-1920". Istorija 20. veka 2/2000.

- Janjetović, Zoran. Deca careva pastorčad kraljeva. Nacionalne manjine u Jugoslaviji 1918-1941. Beograd: INIS, 2005.

- Jovanović, Vladan. Jugoslovenska država i Južna Srbija 1918-1929. Makedonija, Sandžak, Kosovo i Metohija u Kraljevini SHS. Beograd: INIS, 2002.

- $\quad$ Kampus, Eliza. Mica Înțelegere. București: Editura Ştiinţifică, 1968.

- Kimmich, Christoph M.. "Germany and the League of Nations". The League of Nations in retrospect: proceedings of the symposium. Berlin - New York: De Gruyter, 1983.

- $\quad$ Kisindžer, Henri. Diplomatija I. Beograd: Verzal Press, 1999.

- Krivokapić, Boris. „Zaštita manjina između dva svetska rata - osvrt na neke posebne slučajeve". Međunarodni problemi 1-2/2005.

- Krivokapić-Jović, Gordana. Oklop bez viteza. O socijalnim osnovama i organizacionoj strukturi Narodne radikalne stranke u Kraljevini Srba, Hrvata i Slovenaca (1918-1929). Beograd: INIS, 2002. (cyrillic)

- Longvort, Filip. Stvaranje Istočne Evrope. Od preistorije do postkomunizma. Beograd: Clio, 2002. (cyrillic)

- MacMillan, Margaret. Paris 1919: Six Months that Changed the World. New York: Random House, 2002.

- Mazower, Mark, Dark Continent: Europe Twentieth-Century. London: Penguine Books, 1999.

- Mihaylov, Ivan. Spomeni II. Osvoboditelna borba 1919-1924 g. [Louvain], 1965. (cyrillic)

- Mihaylov, Ivan. Spomeni III. Osvoboditelna borba 1919-1924 2. [Louvain], 1967. (cyrillic)

- $\quad$ Mićić, Srđan. „Mala antanta i pitanje manjina pred Društvom naroda 19271934. godine“. Od Moravy k Moravě III: Z historie česko-srbských vztahů, editoři: Václav Štěpánek, Ladislav Hladký, Verica Koprivica. Brno: Matice moravská, Maticí srbskou, 2017. (cyrillic)

- $\quad$ Mićić, Srđan. Od birokratije do diplomatije. Istorija jugoslovenske diplomatske službe 1918-1939. Beograd: INIS, 2018. (cyrillic)

- Milićević, Nataša. „Konstantin Fotić - diplomata od karijere“. Istorija 20. veka, God. XVI, Br. 1 (1998) 
- Milojević, dr Milan Đ. Balkanska ravnoteža: sećanja kraljevog diplomate, priredili Milena Pavlović, Milan Šećerović. Beograd: Signature, 1994. (cyrillic)

- $\quad$ Mitev, Dimitar, sastavitel. Ot Skopie do Ženeva. Dimitar Šalev - zaštitnik na malcinstvata v Obštestvoto na narodite. Sofiya: Logis, 2012. (cyrillic)

- Mitrović, Andrej. Jugoslavija na konferenciji mira 1919-1920. Beograd: Zavod za izdavanje udžbenika, 1969.

- Motta, Giuseppe. Less than Nations: Central-Eastern European Minorities after WWI, Volume I. Newcastle: Cambridge Scholars Publishing, 2013.

- Palešutski, Kostadin. Makedonskiyat vopros v buržoazna Yugoslaviya 19181941. Sofiya: BAN, 1983. (cyrillic)

- $\quad$ Palešutski, Kostadin. Makedonskoto osvoboditelno dviženie sled Perva svetovna voyna (1918-1924). Sofiya: BAN, 1993. (cyrillic)

- Palešutski, Kostadin. Makedonskoto osvoboditelno dviženie 1924-1934. Sofiya: AI „Prof. Marin Drinov“, 1998. (cyrillic)

- $\quad$ Pavlović, Kosta. St. Vojislav Marinković i njegovo doba (1876-1935), knjiga druga. London: M. Caplin \& Co., 1956.

- $\quad$ Poeggel, Walter. "Die Haltung Deutschlands zur Minderheitenfrage". Friedenssichernde Aspekte der Minderheitenschutzes in der Ära des Völkerbundes und der Vereinten Nationen in Europa, Hrsg. Manfred Mohr. Berlin-Heidelberg: Springer-Verlag, 1996.

- $\quad$ Ristić, Ivan T. „Bugarska u politici Kraljevine Srba, Hrvata i Slovenaca (19191929)“. Doktorska disertacija, Univerzitet u Beogradu, Filozofski fakultet, Odeljenje za istoriju, 2017. (cyrillic)

- Sierpowski Stanislaw. "Die Stellung Polens zu dem Bestimmungen des Völkerbundes über die nationalen Minderheiten". Friedenssichernde Aspekte der Minderheitenschutzes in der Ära des Völkerbundes und der Vereinten Nationen in Europa, Hrsg. Manfred Mohr. Berlin-Heidelberg: Springer-Verlag, 1996.

- Seixas, Xosé M. Núñez. “¿Autodeterminación o autonomía cultural? Debates ideológicos en el congreso de nacionalidades Europeas (1925-1939)”. Hispania, Vol. 58, Núm. 3, 1998 doi: 10.3989/hispania.1998.v58.i200.638

- $\quad$ Sládek, Zdeněk. Malá dohoda 1919-1938: Její hospodářské, politické a vojenské komponenty. Praha: Karolinum, 2000.

- Smejkal, Thomas. Protection in Practice: The Minorities Section of the League of Nations Secretariat, 1919-1934. A Bachelor's Theses, Columbia University, 2010.

- $\quad$ Šajti, Enike A. Mađari u Vojvodini 1918-1947. Novi Sad: Forum, 2010.

- Šandanov, Petar. Bogatstvo mi e svobodata. Spomeni. Sofiya: IK „Gutenberg“, 2010. (cyrillic)

- Tasić, Dmitar. „Vojno-politička akcija 'makedonstvujuščih' u Kraljevini SHS/ Jugoslaviji 1919-1934. godine”. Arhiv. Časopis Arhiva Jugoslavije III, 3/2002. (cyrillic) 
- Tasić, Dmitar. "The Institutionalization of Paramilitarism in Yugoslav Macedonia: The Case of the Organization Against the Bulgarian Bandits, 1923-1933". Journal of Slavic Military History, Vol. 32, No. 3, 2019. doi: 10.1080/13518046.2019.1646952

- $\quad$ Tasić, Dmitar. "The Macedonian Youth Secret Revolutionary Organisation (MYSRO) 1922-1927: A New Moment in Macedonian Struggle". Geschichte und Region/Storia e regione, 28. Jahrgang, 2019, Heft 1 - anno XXVIII, 2019, n. 1.

- Vanku, Milan. Mala Antanta 1920-1938. Titovo Užice: IP „Dimitrije Tucović”, 1969.

- Veatch, Richard. "Minorities and the League of Nations". The League of Nations in retrospect: proceedings of the symposium. Berlin - New York: De Gruyter, 1983.

- Weber, Hermann. „Der Minderheitenschutzes des Völkerbundes“. Friedenssichernde Aspekte der Minderheitenschutzes in der Ära des Völkerbundes und der Vereinten Nationen in Europa, Hrsg. Manfred Mohr. Berlin-Heidelberg: Springer-Verlag, 1996.

- $\quad$ Zimmer, Oliver. Nationalism in Europe, 1890-1940. Basingstoke - New York: Macmillan, 2003. 


\title{
Резиме
}

\author{
Срђан Мићић
}

\section{Петиције мањина против југословенских власти пред Друштвом народа}

\begin{abstract}
АПстрАкт: У раду су истражене југословенске тактике у борби против петиција бугарске и мађарске мањине које су подношене Друштву народа и потом промовисане у оквиру Европског конгреса националности. Анализа је заснована на документима сачуваним у Сталној делегацији при Друштву народа у Женеви, која су најрелевантнији извор за проучавање тактика, јер је грађа осталих важних југословенских институција сачувана делимично или фрагментарно.

КљУчнЕ РЕчи: Југославија, права мањина, Друштво народа, Бугари, Мађари
\end{abstract}

Са југословенске тачке гледишта, суштинска разлика у формирању појединих тактика била су средства која су користиле бугарска и мађарска национална мањина током међуратног периода. Постојање мађарске мањине било је признато, она је представљала једну од три највеће мањинске групе, те се није користила комитским ни терористичким активностима. Због тога су њене петиције представљале мању претњу у поређењу са бугарским примером. Jугословенска неактивност је била је уочљива све док расправа Штреземан-Залески није отворила ширу дебату о међународном систему. Она је изазвала иницијативу министра иностраних дела Војислава Маринковића, коју је у потпуности подржао стални делегат у Женеви Константин Фотић. Иста дебата је покренула и серију мађарских и бугарских петиција. Основна југословенска тактика у погледу бугарских петиција била је доказивање везе између мањинских петиционара и терористичких акција које су спровођене на југословенском тлу. Главни изазов су представљале петиције које су потписали Шалев, Анастасов и Илијев, некадашњи званични представници локалног становништва. Југословенске институције су морале да промене приступ, те су биле више фокусиране на дискредитацију личности тројице петиционара него на доказивање њихове подређености 
ВМРО. Ипак, јавно негирање Илијева дотадашње сарадње бугарских петиционара и терористичке организације имало је утицаја на борбу против бугарско-мађарске акције у оквирима Европског конгреса националности. 